\title{
Heavy Metals Contents of Municipal Solid Waste Dumpsites in Potiskum, Yobe State Nigeria
}

\author{
G. D. Ibrahim ${ }^{1,2}$, E. O. Nwaichi ${ }^{3}$, G. O. Abu ${ }^{4}$ \\ ${ }^{1}$ Centre for Occupational Health Safety and Environment, University of Port Harcourt, Port Harcourt, Nigeria \\ ${ }^{2}$ Department of Preliminary Studies, Umar Suleiman College of Education, Gashu'a, Nigeria \\ ${ }^{3}$ Department of Biochemistry, Faculty of Science, University of Port Harcourt, Port Harcourt, Rivers State, Nigeria \\ ${ }^{4}$ Department of Microbiology, Faculty of Science, University of Port Harcourt, Port Harcourt, Rivers State, Nigeria \\ Email: *nodullm@yahoo.com
}

How to cite this paper: Ibrahim, G.D. Nwaichi, E.O. and Abu, G.O. (2020) Heavy Metals Contents of Municipal Solid Waste Dumpsites in Potiskum, Yobe State Nigeria. Journal of Environmental Protection, 11, 709-717.

https://doi.org/10.4236/jep.2020.119043

Received: July 22, 2020

Accepted: September 8, 2020

Published: September 11, 2020

Copyright (c) 2020 by author(s) and Scientific Research Publishing Inc. This work is licensed under the Creative Commons Attribution International License (CC BY 4.0).

http://creativecommons.org/licenses/by/4.0/

\begin{abstract}
The concentrations of $\mathrm{As}, \mathrm{Cd}, \mathrm{Cr}, \mathrm{Cu}, \mathrm{Ni}, \mathrm{Pb}, \mathrm{Fe}$ and $\mathrm{Zn}$ in selected dumpsites in Potiskum were determined with Buck Scientific 210VGB Atomic Absorption Spectrometer (AAS) AVG 210. One-way ANOVA was deployed at $\mathrm{p}$ $<0.05$ level of significance for obtained triplicate values. It was found that the concentration $\left(\mathrm{mg} \cdot \mathrm{kg}^{-1}\right)$ of studied heavy metals in Potiskum dumpsites ranged from $0.108 \pm 0.02-262.536 \pm 0.68$ with pattern of accumulation $\mathrm{Pb}$ $(262.536 \pm 0.02)>\mathrm{Zn}(183.369 \pm 0.58)>\mathrm{Fe}(159.453 \pm 0.50)>\mathrm{Cu}(111.382 \pm$ $0.62)>\mathrm{Cr}(43.523 \pm 0.36)>\mathrm{Ni}(6.419 \pm 0.26)>\mathrm{Cd}(0.679 \pm 0.01)>\mathrm{As}(0.108$ $\pm 0.02) \mathrm{mg} \cdot \mathrm{kg}^{-1}$. The concentrations of $\mathrm{As}, \mathrm{Cr}, \mathrm{Ni}, \mathrm{Fe}$ and $\mathrm{Zn}$ fell below the WHO standards while those of $\mathrm{Pb}, \mathrm{Cd}$ and $\mathrm{Cu}$ were above set limits by WHO. High acidity corresponds markedly with high levels of $\mathrm{Cd}, \mathrm{Cu}, \mathrm{Cr}$ and $\mathrm{Zn}$ and requires urgent attention as this trend is capable of groundwater contamination that will cause public health concern in affected areas.
\end{abstract}

\section{Keywords}

Heavy Metals Concentration, Uptake Pattern, Dumpsites, Municipal Solid Wastes

\section{Introduction}

Any undesirable item resembling trash/garbage or things not regarded as valuable by the owner is considered to be a waste. Municipal solid wastes are unwanted items originating from municipalities in the form of solid [1]. Litters/garbage along the streets of major cities is increasing due to urbanization 
and population sprawl across towns and cities in Nigeria [2].

The daily per capita waste generated in Nigeria is between $0.65-0.95 \mathrm{~kg}$ with an estimate of about 42 million tons of waste yearly out of which $52 \%$ are organic and only $20 \%$ - $30 \%$ are collected and managed [3] [4]. In most cases the wastes are indiscriminately disposed up, the net impact results in obstruction of drainages and causes pollution to water bodies due to lack of effective and efficient waste management program in many towns and cities [5]. According to Mikael et al. [6], there are enforcement bodies and laws at local, state and federal government levels but less achievement had been made to man and to manage waste properly. In Nigeria like most developing nations, open dumping and burning of municipal solid waste are usually considered as the easiest and the cheapest means of waste disposal [4]. There is no centralized and modern system of waste management; rather the system is based on collection, transportation and dumping as well as uncontrolled burning [4]. This action leads to the ejection of hazardous emissions/particles into the environment [7] among which are volatile organic compound (VOCs), particulate matter and semi volatile organic compounds (SVOCS) that result from open burning of waste [8].

Studies by Aboyeji and Eigbokhan [9] indicated indiscriminate burning and dumping of waste as a potential source of leachates contain melted organic matter, inorganic compounds (such as ammonium, calcium, magnesium, sodium, potassium, iron, sulphates, chlorides and heavy metals like cadmium, chromium, copper, lead, zinc and nickel) and can easily infiltrate and pollute the soil and ground water. The extent of the pollution depends on the concentration and toxicity of the contaminants, type and depth of water table as well as direction of groundwater flow. The leachate produced from the municipal solid waste residues can easily leak into water bodies and when consumed by animals transferred to humans through the food chain; they can also serve as a potent source of pollution for both soil and underground water [10]. Soil pollution with heavy metals has become a critical environmental concern [11] [12] due to its potential adverse ecological effects. Heavy metals occur naturally at low concentrations in soils. However, they are considered as soil contaminants due to their widespread occurrence, acute and chronic toxicity. These metals are extremely persistent in the environment. They are non-biodegradable, non-thermo-degradable and thus readily accumulate to toxic levels. Since they do not break down, they might affect the biosphere for a long time. It is known that heavy metals form an important polluting group. They have not only toxic and carcinogenic effects but also tend to accumulate in living organisms [13] (Chopra et al., 2009). Therefore, it is necessary to evaluate the availability of heavy metals in municipal solid waste dumpsite considering it potential degrading potentials on the inhabitants adjacent to dumpsites [14].

\section{Materials and Methods}

\subsection{Study Area}

Potiskum is a town located on latitude $11^{\circ} 43^{\prime} \mathrm{N}$ and longitude $11^{\circ} 04^{\prime} \mathrm{E}$ and is a local government capital of Potiskum local government area in (Figure 1), Yobe 
state, Nigeria with an estimated area of about $559 \mathrm{Km}$ and a total population of about 205,876 as at 2006 [15]. The selected dumpsites are provided and controlled by local government authority, open burning and deposition is the waste management practiced in these selected dumpsites. In addition, these dumpsites contain similar kind of waste mainly household, animal dung and waste from commercial facilities.

\subsection{Samples and Sampling}

Table 1 provides the GPS location, dimension and the number of soil samples collected from each dumpsite. Soil samples were collected at a depth of 15 - 30 $\mathrm{cm}$ with soil auger using grid soil sampling from the selected dumpsites based on

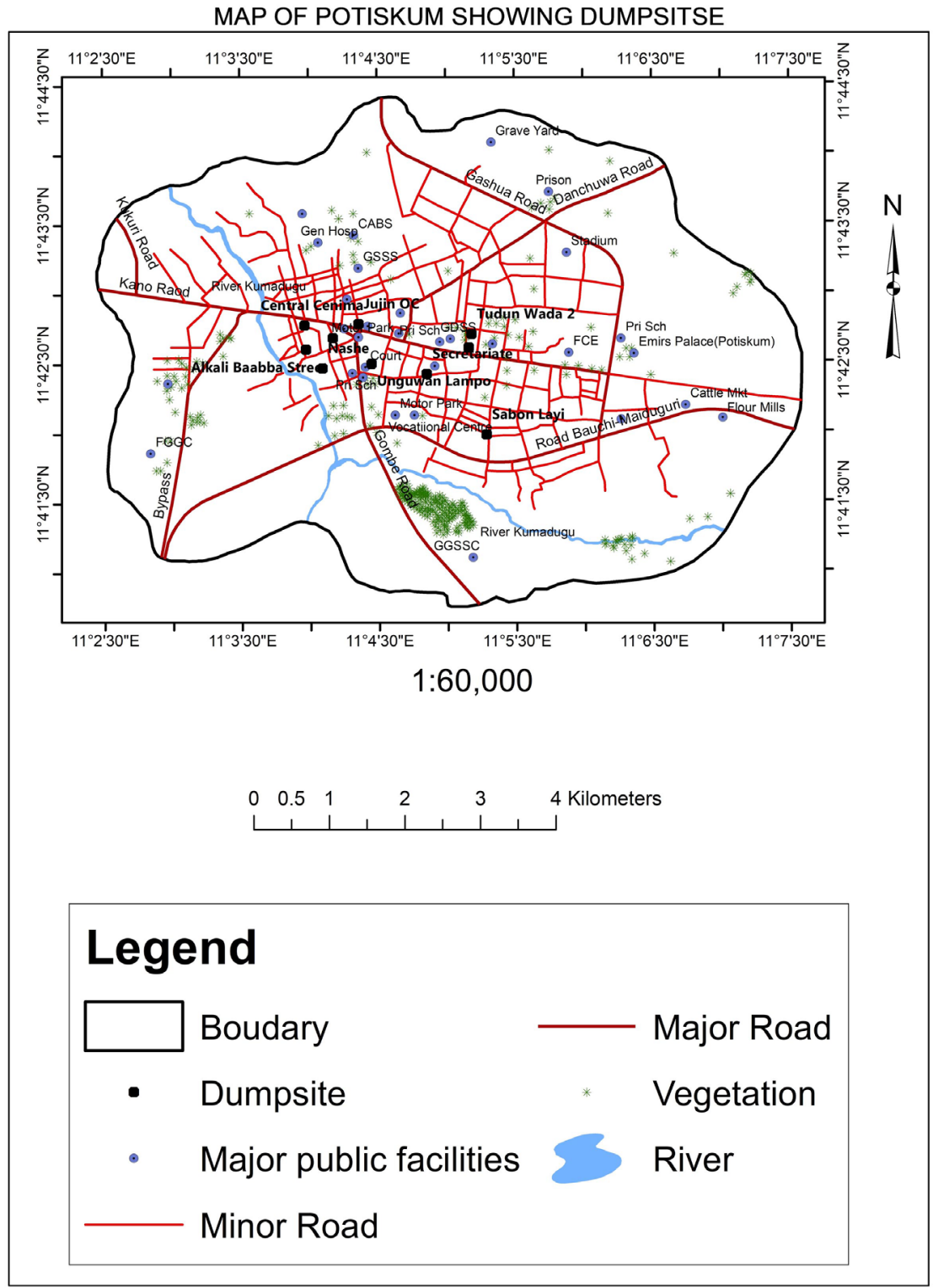

Figure 1. Map of Potiskum local government area showing the chosen dumpsites (map created by authors). 
Table 1. Dumpsites location, size and the numbers samples collected per dumpsites.

\begin{tabular}{cccccc}
\hline S/No & Dumpsites & Longitude & Latitude & Dimension & $\begin{array}{c}\text { No. of Samples } \\
\text { Collected }\end{array}$ \\
\hline $\mathbf{1}$ & DS1 & $11^{\circ} 05^{\prime} 17.2^{\prime \prime} \mathrm{E}$ & $11^{\circ} 41^{\prime} 59.4^{\prime \prime} \mathrm{N}$ & 9 m length 7 m width & 24 replicates \\
$\mathbf{2}$ & DS2 & $11^{\circ} 05^{\prime} 09.3^{\prime \prime} \mathrm{E}$ & $11^{\circ} 42^{\prime} 37.0^{\prime \prime} \mathrm{N}$ & 4 m length $4 \mathrm{~m}$ width & 18 replicates \\
$\mathbf{3}$ & DS3 & $11^{\circ} 05^{\prime} 10.6^{\prime \prime} \mathrm{E}$ & $11^{\circ} 42^{\prime} 42.7^{\prime \prime} \mathrm{N}$ & 9 m length $5 \mathrm{~m}$ width & 18 replicates \\
$\mathbf{4}$ & DS4 & $11^{\circ} 04^{\prime} 51.0^{\prime \prime} \mathrm{E}$ & $11^{\circ} 42^{\prime} 25.4^{\prime \prime} \mathrm{N}$ & $7.1 \mathrm{~m}$ length $6.5 \mathrm{~m}$ width & 12 replicates \\
$\mathbf{5}$ & DS5 & $11^{\circ} 04^{\prime} 27.2^{\prime \prime} \mathrm{E}$ & $11^{\circ} 42^{\prime} 30.2^{\prime \prime} \mathrm{N}$ & $17.5 \mathrm{~m}$ length $28 \mathrm{~m}$ width & 24 replicates \\
$\mathbf{6}$ & DS6 & $11^{\circ} 04^{\prime} 05.3^{\prime \prime} \mathrm{E}$ & $11^{\circ} 42^{\prime} 27.9^{\prime \prime} \mathrm{N}$ & $10.5 \mathrm{~m}$ length $10.5 \mathrm{~m}$ width & 38 replicates \\
$\mathbf{7}$ & DS7 & $11^{\circ} 03^{\prime} 57.7^{\prime \prime} \mathrm{E}$ & $11^{\circ} 42^{\prime} 36.4^{\prime \prime} \mathrm{N}$ & $17 \mathrm{~m}$ length $9 \mathrm{~m}$ width & 18 replicates \\
$\mathbf{8}$ & DS8 & $11^{\circ} 03^{\prime} 58.0^{\prime \prime} \mathrm{E}$ & $11^{\circ} 42^{\prime} 46.3^{\prime \prime} \mathrm{N}$ & $16 \mathrm{~m}$ length $5 \mathrm{~m}$ width & 14 replicates \\
$\mathbf{9}$ & DS9 & $11^{\circ} 04^{\prime} 09.9^{\prime \prime} \mathrm{E}$ & $11^{\circ} 42^{\prime} 41.7^{\prime \prime} \mathrm{N}$ & $14.5 \mathrm{~m}$ length $11 \mathrm{~m}$ width & 18 replicates \\
$\mathbf{1 0}$ & DS10 & $11^{\circ} 04^{\prime} 21.1^{\prime \prime} \mathrm{E}$ & $11^{\circ} 42^{\prime} 47.5^{\prime \prime} \mathrm{N}$ & $17.5 \mathrm{~m}$ length $4.5 \mathrm{~m}$ width & 12 replicates \\
\hline
\end{tabular}

$\mathrm{n}$; the numbers of sample collected on each dumpsite depends largely on the size of the dumpsite as shown in Table 1 and they were collected at random to ensure adequacy and representativeness of the samples and sampling. The bulked sample collected from each dumpsite were then placed in a labelled polyethylene bag and transported to the laboratory for pretreatment.

The dumpsites are represented with DS while subscript attached represents the number of the dumpsites.

\subsection{Analysis}

Soil samples were digested by dissolving $0.2 \mathrm{~g}$ soil in $6 \mathrm{ml}$ of concentrated nitric acid $\left(\mathrm{HNO}_{3}\right), 2 \mathrm{ml}$ of concentrated hydrochloric acid $(\mathrm{HCl})$ and $2 \mathrm{ml}$ of hydrofluoric acid (HF) in a SINEO MASTER 40 microwave digester at a temperature of $120^{\circ} \mathrm{C}$ for $15 \mathrm{~m}, 160^{\circ} \mathrm{C}$ for $10 \mathrm{~m}, 180^{\circ} \mathrm{C}$ for $20 \mathrm{~m}$ and $200^{\circ} \mathrm{C}$ for $30 \mathrm{~m}$ respectively. The concentrations of the heavy metals $\mathrm{As}, \mathrm{Fe}, \mathrm{Cd}, \mathrm{Cr}, \mathrm{Cu}, \mathrm{Ni}, \mathrm{Pb}$ and $\mathrm{Zn}$ in the solution were analyzed with Buck Scientific 210VGB Atomic Absorption Spectrometer (AAS) following manufacturers' protocol.

\subsection{Statistical Analysis}

One-way ANOVA was deployed to establish significance variations at $\mathrm{p}<0.05$ in the concentration of heavy metals in the soil samples from the selected dumpsites.

\section{Results and Discussion}

Figure 2 presents the mean dumps soil $\mathrm{pH}$ and electrical conductivities in $\left(\mathrm{mS} \cdot \mathrm{m}^{-1}\right)$.

\subsection{Physicochemical Parameters of Some Dumpsites}

The mean soil $\mathrm{pH}$ ranged from slightly acidic to strongly alkaline with an average 


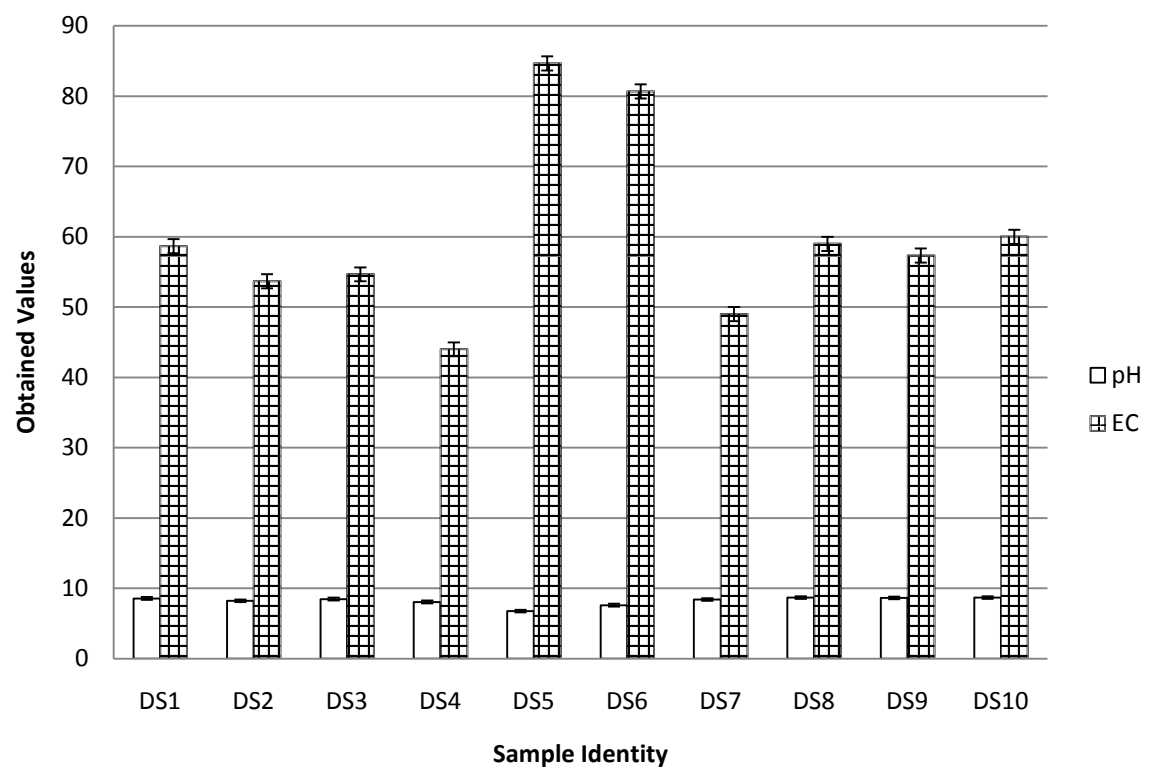

Figure 2. Mean $\pm \mathrm{SE}(\mathrm{n}=10)$ values for $\mathrm{pH}$ and $\mathrm{EC}$ of soil samples from studied dumpsites. DS means dumpsites and the assigned numbers show they were ten dumpsites.

values ranged between $6.770 \pm 0.05-8.677 \pm 0.01$, the soils are mostly alkaline except in DS5 and DS6 which are slightly acidic and slightly neutral with $\mathrm{pH}$ values of $6.770 \pm 0.05$ and $7.610 \pm 0.18$ respectively (Figure 2). The mean $\mathrm{pH}$ values of dump soil obtained in Potiskum dumpsite DS5 was found to be lower than the mean values reported by Anake et al. [16] for similar sites in Kano and Kaduna. The dumps soil in some of the dumpsite in Potiskum were found to be more acidic than dumps soils reported in [16]. The mean electrical conductivity (E.C) of dumps soil in Potiskum ranged from $44.000 \pm 0.58-84.667 \pm 0.33$ in DS4 and DS5 respectively, values that are lower than the range obtained in Adesewa and Morenikeji [17] and Emereibeole et al. [18]. Anake et al. [16] found the $\mathrm{pH}$ of some dumpsites in Kano and Kaduna range between $7.23 \pm 0.17-7.75 \pm$ 0.47. Studies on physicochemical properties of soils from choice dumpsites in Owerri revealed mean $\mathrm{pH}$ level of 3.60 - 6.90 with E.C ranging from 10.00 $95.00 \mathrm{mS} \cdot \mathrm{m}^{-1}$ [18]. The analysis of $\mathrm{pH}$ and E.C of soil from Awotan dumpsites in Ibadan revealed $8.0 \pm 1.8-8.2 \pm 0.2$ and $327.1 \pm 87.2-724.2 \pm 226.4 \mathrm{mS} \cdot \mathrm{cm}^{-1}$ respectively [17].

\subsection{Concentration of Heavy Metals in the Selected Dumpsites}

Table 2 showed the concentration of the selected heavy metals in these dumpsites, As and Cd concentrations were the least among the studied metals. The concentrations were found to be $0.270 \pm 0.00,0.067 \pm 0.01,0.130 \pm 0.02,0.197 \pm$ $0.04,0.100 \pm 0.02,0.070 \pm 0.02,0.080 \pm 0.00,0.077 \pm 0.01,0.053 \pm 0.01,0.033 \pm$ $0.02\left(\mathrm{mg} \cdot \mathrm{kg}^{-1}\right)$ respectively for DS1, DS2, DS3, DS4, Ds5, DS6, DS7, DS8, DS9 and DS10. While that of Cd ranged between $0.073 \pm 0.01,0.737 \pm 0.03,1.150 \pm$ $0.00,0.700 \pm 0.02,1.750 \pm 0.00,1.140 \pm 0.00,0.580 \pm 0.00,0.413 \pm 0.01$, not detected and $0.247 \pm 0.01\left(\mathrm{mg} \cdot \mathrm{kg}^{-1}\right)$ in DS1, DS2, DS3, DS4, DS5, DS6, DS7, DS8, 
Table 2. Mean \pm SE levels of heavy metals in the selected dumpsites $\left(\mathrm{mg} \cdot \mathrm{kg}^{-1}\right)$.

\begin{tabular}{ccccccccc}
\hline Dumpsite & As & $\mathrm{Cd}$ & $\mathrm{Cr}$ & $\mathrm{Cu}$ & $\mathrm{Ni}$ & $\mathrm{Pb}$ & $\mathrm{Fe}$ & $\mathrm{Zn}$ \\
\hline DS1 & $0.270 \pm 0.00$ & $0.073 \pm 0.01$ & $28.067 \pm 0.19$ & $63.008 \pm 1.38$ & $5.668 \pm 0.52$ & $11.538 \pm 0.00$ & $193.056 \pm 0.37$ & $201.564 \pm 0.33$ \\
DS2 & $0.067 \pm 0.01$ & $0.737 \pm 0.03$ & $34.337 \pm 0.30$ & $117.886 \pm 0.07$ & $7.1685 \pm 0.45$ & $312.821 \pm 0.70$ & $213.856 \pm 0.56$ & $180.468 \pm 0.65$ \\
DS3 & $0.130 \pm 0.02$ & $1.150 \pm 0.00$ & $35.537 \pm 0.31$ & $77.236 \pm 2.03$ & $6.2724 \pm 0.12$ & $207.407 \pm 0.10$ & $104.412 \pm 0.90$ & $168.161 \pm 0.87$ \\
DS4 & $0.197 \pm 0.04$ & $0.700 \pm 0.02$ & $60.870 \pm 0.37$ & $113.821 \pm 1.07$ & $7.661 \pm 0.21$ & $146.51 \pm 1.28$ & $172.600 \pm 0.34$ & $195.411 \pm 0.57$ \\
DS5 & $0.100 \pm 0.02$ & $1.750 \pm 0.00$ & $59.840 \pm 0.50$ & $130.081 \pm 1.03$ & $6.944 \pm 0.11$ & $295.014 \pm 0.56$ & $193.056 \pm 0.36$ & $212.992 \pm 0.83$ \\
DS6 & $0.070 \pm 0.02$ & $1.140 \pm 0.00$ & $46.637 \pm 0.44$ & $123.984 \pm 0.03$ & $6.272 \pm 0.22$ & $112.322 \pm 0.36$ & $227.150 \pm 0.09$ & $197.170 \pm 0.34$ \\
DS7 & $0.080 \pm 0.00$ & $0.580 \pm 0.00$ & $42.220 \pm 0.65$ & $81.301 \pm 0.04$ & $8.286 \pm 0.12$ & $111.966 \pm 0.00$ & $124.869 \pm 0.93$ & $38.942 \pm 0.89$ \\
DS8 & $0.077 \pm 0.01$ & $0.413 \pm 0.01$ & $42.463 \pm 0.32$ & $150.407 \pm 0.01$ & $4.0323 \pm 0.00$ & $336.325 \pm 3.70$ & $186.242 \pm 0.02$ & $196.290 \pm 0.33$ \\
DS9 & $0.053 \pm 0.01$ & $\mathrm{ND}$ & $45.507 \pm 0.26$ & $115.854 \pm 0.00$ & $2.912 \pm 0.22$ & $850.570 \pm 0.03$ & $158.962 \pm 0.65$ & $265.735 \pm 0.95$ \\
DS10 & $0.033 \pm 0.02$ & $0.247 \pm 0.01$ & $39.750 \pm 0.26$ & $140.244 \pm 0.52$ & $8.961 \pm 0.59$ & $240.883 \pm 0.10$ & $220.331 \pm 0.74$ & $176.952 \pm 0.05$ \\
\hline
\end{tabular}

DS1 - Dumpsite 1, DS2 - Dumpsite 2, DS3 - Dumpsite 3, DS4 - Dumpsite 4, DS5 - Dumpsite 5, DS6 - Dumpsite 6, DS7 - Dumpsite 7, DS8 - Dumpsite 8, DS9 - Dumpsite 9 and DS10 - Dumpsite 10 and ND - not detected. The Standards Set for studied heavy metals in soils by WHO are; As: $40 \mathrm{mg} \cdot \mathrm{kg}^{-1}$, Cd: 0.8 $\mathrm{mg} \cdot \mathrm{kg}^{-1}$, Cr: $100 \mathrm{mg} \cdot \mathrm{kg}^{-1}, \mathrm{Cu}: 100 \mathrm{mg} \cdot \mathrm{kg}^{-1}, \mathrm{Ni}: 35 \mathrm{mg} \cdot \mathrm{kg}^{-1}, \mathrm{~Pb}: 85 \mathrm{mg} \cdot \mathrm{kg}^{-1}$, Fe: $7000 \mathrm{mg} \cdot \mathrm{kg}^{-1}$ and Zn: $300 \mathrm{mg} \cdot \mathrm{kg}^{-1}$.

DS9 and DS10 respectively. Observed arsenic concentrations in these dumpsites were below the WHO permissible limits in $\mathrm{mg} \cdot \mathrm{kg}^{-1}$ of 40 set by the world health organization for soils while concentration of $\mathrm{Cd}$ was below the standards of 0.8 $\mathrm{mg} \cdot \mathrm{kg}^{-1}$ in DS1, DS2, DS4, DS7, DS8 and DS10, exceeded in DS3, DS5, DS6 and not detected in DS9 [19]. Results of the correlation analysis also showed strong negative correlation between As with $\mathrm{Cd}, \mathrm{Cr}, \mathrm{Cu}, \mathrm{Ni}, \mathrm{Pb}$ and $\mathrm{Fe}$ but have weak negative correlation with $\mathrm{Zn}$ (Table 3).

Chromium, nickel, iron and zinc concentrations in $\mathrm{mg} \cdot \mathrm{kg}^{-1}$ of $100,35,7000$ and 300 permissible limits set by WHO respectively were not exceeded in all the dumpsites, $\mathrm{Cu}$ concentration exhibit strong negative correlation with $\mathrm{Ni}$ but has weak positive correlation with $\mathrm{Pb}$ and $\mathrm{Zn}$ (Table 3). The concentrations of $\mathrm{Cr}$ and $\mathrm{Ni}$ in these dumpsites ranged between $28.067 \pm 0.19,34.337 \pm 0.30,35.537 \pm$ $0.31,60.870 \pm 0.37,59.840 \pm 0.50,46.637 \pm 0.44,42.220 \pm 0.65,42.463 \pm 0.32$, $45.507 \pm 0.26$ and $39.750 \pm 0.26$ while the observed concentration of Ni were $5.668 \pm 0.52,7.1685 \pm 0.45,6.2724 \pm 0.12,7.661 \pm 0.21,6.944 \pm 0.11,6.272 \pm$ $0.22,8.286 \pm 0.12,4.0323 \pm 0.00,2.912 \pm 0.22$ and $8.961 \pm 0.59$ respectively for DS1, Ds2, DS3, DS4, DS5, DS6, DS7, DS8, DS9 and DS10 (Table 2).

The content of copper observed in these dumpsites exceeded the WHO permissible limits in $\mathrm{mg} \cdot \mathrm{kg}^{-1}$ of 100 except in DS1, DS3 and DS7. Observed copper concentration showed strong negative correlation with $\mathrm{Ni}$ but has weak negative correlation with $\mathrm{Pb}, \mathrm{Fe}$ and $\mathrm{Zn}$ (Table 3). The concentration was $63.008 \pm 1.38$, $117.886 \pm 0.07,77.236 \pm 2.03,113.821 \pm 1.07,130.081 \pm 1.03,123.984 \pm 0.03$, $81.301 \pm 0.04,150.407 \pm 0.01,115.854 \pm 0.00$ and $140.244 \pm 0.52 \mathrm{mg} \cdot \mathrm{kg}^{-1}$ for DS1, DS2, DS3, DS4, DS5, DS6, DS7, DS8, DS9 and DS10 respectively.

Table 2 showed that $\mathrm{Pb}$ concentration in the selected dumpsites fell above the WHO permissible limits of $85 \mathrm{mg} \cdot \mathrm{kg}^{-1}$ of except in DS1 with concentration of $11.538 \pm 0.00,312.821 \pm 0.70,207.407 \pm 0.10,146.51 \pm 1.28,295.014 \pm 0.56$, 
Table 3. Correlation coefficient (r) for selected heavy metals in Potiskum dumpsites.

\begin{tabular}{ccccccccc}
\hline & $\mathrm{As}$ & $\mathrm{Cd}$ & $\mathrm{Cr}$ & $\mathrm{Cu}$ & $\mathrm{Ni}$ & $\mathrm{Pb}$ & $\mathrm{Fe}$ & $\mathrm{Zn}$ \\
\hline $\mathrm{As}$ & 1 & & & & & & & \\
$\mathrm{Cd}$ & -0.09356 & 1 & & & & & & \\
$\mathrm{Cr}$ & -0.11095 & 0.487347 & 1 & & & & & \\
$\mathrm{Cu}$ & -0.63995 & 0.118235 & 0.462966 & 1 & & & & \\
$\mathrm{Ni}$ & -0.01617 & 0.294681 & 0.109406 & -0.07221 & 1 & & & \\
$\mathrm{~Pb}$ & -0.51002 & -0.26666 & 0.150556 & 0.373851 & -0.6346 & 1 & & \\
$\mathrm{Fe}$ & -0.15099 & -0.02691 & 0.051028 & 0.575319 & 0.112785 & -0.09179 & 1 & \\
$\mathrm{Zn}$ & 0.069744 & -0.07915 & 0.178475 & 0.366681 & -0.61707 & 0.544059 & 0.398163 & 1 \\
\hline
\end{tabular}

The value of correlation coefficient ( $r$ ) was calculated using SPSS $\mathrm{v} 20$.

$112.322 \pm 0.36,111.966 \pm 0.00,36.325 \pm 3.70,850.570 \pm 0.03$ and $240.883 \pm 0.10$ for DS1, DS2, DS3, DS4, DS5, DS6, DS7, DS8, DS9 and DS10 respectively. Lead concentration showed strong negative correlation with Fe but have weak positive correlation with $\mathrm{Zn}$ (Table 3).

\section{Conclusion}

The concentrations of $\mathrm{As}, \mathrm{Cd}, \mathrm{Cr}, \mathrm{Cu}, \mathrm{Ni}, \mathrm{Pb}, \mathrm{Fe}$ and $\mathrm{Zn}$ were evaluated in selected dumpsites from Potiscum; the mean concentrations of metals from these dumpsites in $\mathrm{mg} \cdot \mathrm{kg}^{-1}$ were found to be in the sequence $\mathrm{Pb}>\mathrm{Zn}>\mathrm{Fe}>\mathrm{Cu}>\mathrm{Cr}>$ $\mathrm{Ni}>\mathrm{Cd}>\mathrm{As}$ with strong positive correlations between $\mathrm{Pb}$ and $\mathrm{Zn}$. Elevated concentrations of $\mathrm{Pb}, \mathrm{Cd}$ and $\mathrm{Cr}$ above WHO standards call for reasoned and careful monitoring as these persistent metals are capable of accumulation over time along the food chain. These worrisome levels of $\mathrm{Pb}, \mathrm{Cd}$ and $\mathrm{Cr}$ suggest that municipal solid wastes are sinks of heavy metals and therefore require treatment before application as soil conditioners.

\section{Conflicts of Interest}

The authors declare no conflicts of interest regarding the publication of this paper.

\section{References}

[1] Suleiman, M.B., Santuraki, A.H., Abubakar, I.K. and Henry, O.O. (2018) Geo-Accumulation and Contamination Status of Heavy Metals in Selected MSW Dumpsites Soil in Gombe, Nigeria. Bima Journal of Science and Technology, 2, 31-41.

[2] Ogunjuyigbe, A.S.O., Ayodele, T.R. and Alao, M.A. (2017) Electricity Generation from Municipal Solid Waste in Some Selected Cities of Nigeria: An Assessment of Feasibility, Potential and Technologies. Renewable and Sustainable Energy Reviews, 80, 149-162. https://doi.org/10.1016/j.rser.2017.05.177

[3] Ike, C.C., Ezeibe, C.C., Anijiofor, S.C. and Daud, N.N. (2018) Solid Waste Management in Nigeria: Problems, Prospects, and Policies. The Journal of Solid Waste 
Technology and Management, 44, 163-172. https://doi.org/10.5276/JSWTM.2018.163

[4] Rukwe, A., Eggen, T. and Moder, M. (2012) Solid Waste Deposits as a Significant Source of Contaminants of Emerging Concern to the Aquatic and Terrestrial Environments-A Developing Country Case Study from Owerri, Nigeria. Science of the Total Environment, 438, 94-102. https://doi.org/10.1016/j.scitotenv.2012.08.039

[5] Adeniran, A.E., Nubi, A.T. and Adelopo, A.O. (2017) Solid Waste Generation and Characterization in the University of Lagos for a Sustainable Waste Management. Waste management, 6, 3-10. https://doi.org/10.1016/j.wasman.2017.05.002

[6] Michael, E.O. (2015) Effect of Solid Waste Source (Dumpsite Type) on Heavy Metal Contaminations in Urban Soils of Bauchi, Nigeria. American Chemical Science Journal, 9, 1-14.

[7] Nwaichi, E.O., Uwakwe, A.A. and George, M.S. (2020) Water Quality and Hydrocarbon Contaminant Level in Soil and Fishes around Abuloma Jetty, Port Harcourt, Nigeria. Journal of Environmental Science and Technology, 13, 106-117. https://doi.org/10.3923/jest.2020.106.117

[8] Estrellan, C.R. and Iino, F. (2010) Toxic Emissions from Open Burning. Chemosphere, 80, 193-207. https://doi.org/10.1016/j.chemosphere.2010.03.057

[9] Aboyeji, O.S. and Eigbokhan, S.F. (2016) Evaluations of Groundwater Contamination by Leachates around Olusosun Open Dumpsite in Lagos Metropolis, Southwest Nigeria. Journal of Environmental Management, 1, 333-341.

https://doi.org/10.1016/j.jenvman.2016.09.002

[10] Adedara, I.A., Oyebiyi, O.O., Lawal, T.A., Adesina, A.A. and Farombi, E.O. (2013) Involvement of Oxidative Stress in Municipal Landfill Leachate-Induced Toxicity in Boar Sperm. Environmental Toxicology and Pharmacology, 36, 972-978. https://doi.org/10.1016/j.etap.2013.08.012

[11] Nwaichi, E.O. and Parkash, O. (2016) Heavy metals Contaminated Environments and the Road Map with Phytoremediation. Journal of Environmental Protection, 7, 41-51. https://doi.org/10.4236/jep.2016.71004

[12] Onyejekwe, I.M., Osuji, L.C. and Nwaichi, E.O. (2019) Accumulation of Heavy Metal in the Seeds of Zea Mays L. from Crude Oil Impacted Soils in Kom-Kom, Rivers State, Nigeria. Journal of Scientific Research \& Reports, 25, 1-8. https://doi.org/10.9734/jsrr/2019/v25i3-430182

[13] Chopra, A.K. and Pathak, C. (2012) Enrichment and Translocation of Heavy Metals in Soil and Spinacea oleracea Grown in Sugar Mill Effluent Irrigated Soil. Sugar Tech, 15, 77-83. https://doi.org/10.1007/s12355-012-0194-5

[14] Edosomwan, N.L and Onwumah, B.I. (2008) Impact of Municipal Solid Waste on Some Soil Properties in Central Southern Nigeria. Indian Journal of Agricultural Resources, 42, 244-251.

[15] Bigwan, E.I., Tinja, B. and Damen, J.G. (2012) Prevalence of Schistosomiasis among Secondary School Boarding Students in Potiskum Metropolis, Yobe State, North-Eastern Nigeria. Bayero Journal of Pure and Applied Sciences, 5, 155-158. https://doi.org/10.4314/bajopas.v5i1.27

[16] Anake, W.U., Adie, G.U. and Osibanjo, O. (2009) Heavy Metals Pollution at Municipal Solid Waste Dumpsites in Kano and Kaduna States in Nigeria. Bulletin Chemical Society of Ethiopia, 23, 281-289. https://doi.org/10.4314/bcse.v23i2.44972

[17] Adesewa, A. and Morenikeji, O. (2017) Helminths and Heavy Metals in Soils from a Dumpsite in Ibadan City, Nigeria. Journal of Preventive Medicine and Hygiene, 58, E328-333. 
[18] Emereibeole, E.I., Ononibaku, I.F., Ejiogu, C.C. and Ebe, T.E. (2017) Assessment of the Levels of Some Heavy Metals in Soils around the Nekede Dumpsite in Owerri, Nigeria. Futo Journal Series, 3, 131-137.

[19] WHO (1996) World Health Organization.

https://www.omicsonline.org/articles-images/2161-0525-5-334-t011.html 